THE ANTIOXIDANT AND ANTIAPOPTOTIC EFFECT OF BORIC ACID ON HEPATOXICITY IN CHRONIC ALCOHOL-FED RATS

\begin{tabular}{|c|c|}
\hline Journal: & Canadian Journal of Physiology and Pharmacology \\
\hline Manuscript ID & cjpp-2017-0487.R1 \\
\hline Manuscript Type: & Article \\
\hline Date Submitted by the Author: & 11-Aug-2017 \\
\hline Complete List of Authors: & $\begin{array}{l}\text { Sogut, Ibrahim; Istanbul Bilim University, Vocational School of Health } \\
\text { Services } \\
\text { Paltun, Sıla; Istanbul Bilim University, Faculty of Medicine, Department of } \\
\text { Histology and Embryology } \\
\text { Tuncdemir, Matem ; Istanbul University, Faculty of Medicine, Department } \\
\text { of Medical Biology } \\
\text { Ersoz, Melike; Istanbul Bilim University, Faculty of Arts and Sciences, } \\
\text { Department of Molecular Biology and Genetics } \\
\text { Hurdag, Canan; Istanbul Bilim University, Faculty of Medicine, Department } \\
\text { of Histology and Embryology }\end{array}$ \\
\hline $\begin{array}{r}\text { Is the invited manuscript for } \\
\text { consideration in a Special } \\
\text { Issue?: }\end{array}$ & N/A \\
\hline Keyword: & $\begin{array}{l}\text { apoptosis, boric acid, chronic ethanol consumption, oxidative stress, } \\
\text { hepatotoxicity }\end{array}$ \\
\hline
\end{tabular}




\title{
THE ANTIOXIDANT AND ANTIAPOPTOTIC EFFECT OF BORIC ACID ON HEPATOXICITY IN CHRONIC ALCOHOL-FED RATS
}

\author{
Ibrahim Sogut ${ }^{1}$, Sıla Ozlem Paltun ${ }^{2}$, Matem Tuncdemir ${ }^{3}$, \\ Melike Ersoz ${ }^{4}$, Canan Hurdag ${ }^{2}$ \\ 1-Vocational School of Health Services, Istanbul Bilim University, Istanbul, Turkey \\ 2-Department of Histology and Embryology, Faculty of Medicine, Istanbul Bilim University, Istanbul, \\ Turkey \\ 3- Department of Medical Biology, Faculty of Medicine, Istanbul University, Istanbul, Turkey \\ 4-Department of Molecular Biology and Genetics, Faculty of Arts and Sciences, Istanbul Bilim \\ University, Istanbul, Turkey
}

\section{E-mail addresses:}

ibrahim.sogut@gmail.com

silapaltun@gmail.com

matemtuncdemir@gmail.com

mersoz1@yahoo.com

canan.hurdag@istanbulbilim.edu.tr

Running head: Ethanol \& boric acid effect on hepatoprotective

*Corresponding Author: Ass.Prof. Ibrahim SOGUT

Istanbul Bilim University, Vocational School of Health Services,

Yazarlar Sok. No:17 34394 Esentepe, Sisli / Istanbul

Current address: Otto-Von-Guericke University Magdeburg/Germany, Department of Clinic Chemistry and Pathochemistry

Email adres: ibrahim.sogut@gmail.com, ibrahim.soeguet@med.ovgu.de

Phone: (90) 5061711855 (TR), 015147104591 (D)

Fax: (90) 2122758954 


\begin{abstract}
The harmful use alcohol is a worldwide problem involving all ages. This study aims to investigate chronic alcohol exposure related hepatotoxicity on the rats liver and possible hepatoprotective effects of boric acid. Rats were separated into four different group: control, ethanol, ethanol+boric acid and boric acid. We measured malondialdehyde levels (MDA), total sialic acid (TSA), superoxide dismutase (SOD), catalase (CAT) and glutathione peroxidase (GPx) levels which are known to be the markers of alcohol damage and also caspase-3, tumor necrosis factor-alpha (TNF- $\alpha$ ) and the terminal deoxynucleotidyl transferase dUTP nick-end labeling (TUNEL) as the markers of apoptosis were measured. In ethanol group MDA, TSA and TNF- $\alpha$ levels increased whereas SOD and CAT levels decreased compared with control group. Ethanol+boric acid group MDA, TSA, caspase-3 and TNF- $\alpha$ levels decreased whereas SOD and CAT levels increased compared with ethanol group. Histopathological evaluation of light microscope images, immunohistochemical caspase- 3 and TNF- $\alpha$ activity in the ethanol+boric acid group were shown to be decreased compared with that in the ethanol group. Our result revealed that ethanol is capable of triggering oxidative stress and apoptosis in the rat liver. We propose that boric acid is an effective compound in protecting the rat liver against ethanol.
\end{abstract}

Keywords: Apoptosis, boric acid, chronic alcohol consumption, hepatotoxicity, oxidative stress 


\section{INTRODUCTION}

Alcohol is a toxin that causes serious damage on many organs depending on the dose and duration of use. Chronic alcohol consumption is the most important factor that leads to cirrhosis, liver failure and cancer (Lieber 1997; Poschl and Seitz 2004). In addition to that, it is a serious health problem throughout the world; approximately $4 \%$ of all deaths worldwide are attributed to alcohol (WHO 2011).

Toxicity of ethanol in liver can occur via direct effects of ethanol or its metabolites. Ethanol is metabolized into acetaldehyde by oxidative metabolism (Lieber 1997). These reactions increase generation of superoxide $\left(\mathrm{O}_{2}^{-*}\right)$, hydrogen peroxide $\left(\mathrm{H}_{2} \mathrm{O}_{2}\right)$ and hydroxyl radicals $(\cdot \mathrm{OH})$ due to elevated activity in respiratory chain (Brocardo et al. 2011). Various defence mechanisms exist in order to prevent cellular damage caused by reactive oxygen species, for example superoxide dismutase (SOD), catalase (CAT) and glutathione peroxidase (GPx) (Brocardo et al. 2011).

Previous studies revealed that chronic alcohol consumption related oxidative stress triggers apoptotic cell death. Ethanol induces apoptosis through three pathways (Chandramoorthy et al. 2012; ManzoAvalos and Saavedra-Molina 2010). First pathway also known as "Intrinsic pathway" causes apoptosis through mitochondria and triggered apoptotic signals such as ROS and DNA damage. Second pathway is called "extrinsic pathway" and acts through cell mebrane receptor-ligand association of apoptosis triggering factors such as alcohol. The third patway is called "caspase independent pathway" in which apoptosis inducing factor (AIF), directly inhibit DNAse or polyadenosinephosphate ribose polymerase (PARP) activity and generates apoptosis through mitochondrial way (Chandramoorthy et al. 2012; Mooney et al. 2006).

For the first time, this possible effect of boric acid will be tested with a rat model of chronic alcohol consumption. Boric acid (BA) is lewis acid. Due to this property BA has inhibitory effect on enzymes like peptidases, aldehyde dehydrogenase, proteases, xanthine oxidase, nitric oxide synthase and 
cytochrome $\mathrm{b}$ reductase. BA affects the levels of ions like calcium, magnesium and potassium, vitamin D, insuline, estrogen, testosterone and glucose metabolism. It also has strong affinity to S-adenosyl methionine (SAM). Hydroxyl group containing molecules such as glycolipids and glycoproteins can form a complex with BA which alters membrane integrity (Hunter 2005; Nielsen 2008). BA is used as an antioxidant and anti-inflammatory agent in cancer and inflammatory disease treatments, wound healing, prevention of oxidative stres, reducing the toxic effects of heavy metals and regulating mitochondrial membrane potential (Henderson et al. 2009; Sogut et al. 2015; Ustundag et al. 2014). Furthermore, BA has restored the activity of the acetylcholinesterase which is inhibited by pesticides (Coban et al. 2015) and also is prevented from cyclophosphamide-induced and carbon tetrachlorideinduced oxidative stress (Ince et al. 2012; Ince et al. 2014).

The aim of this study is to investigate the possible preventive effects of boric acid administration on oxidative damage and apoptosis related to chronic ethanol consumption.

\section{MATERIALS AND METHODS}

\section{Animals and laboratory condition}

Adult thirty-two male Spraque-Dawley rats of the three mount-old and same weighing (250-260g) were purchased from TUBITAK Marmara Research Center. Rats were housed in transparent plexiglas cages in an environmentally controlled, clean-air room with temperature $\left(22 \pm 3^{\circ} \mathrm{C}\right), 12 \mathrm{~h}-12 \mathrm{~h}$ lightdark cycle, and a relavite humidity of $60 \pm 5 \%$. All experimental procedures were conducted in accordance with the guidelines of Bezmialem University Institutional Animal Ethics Committee (Protocol no: 2013/27) and with the Guide for the Care and Use of Laboratory Animals prepared by the National Academy of Sciences.

\section{Experimental procedure}

Rats were separated into four different group: control (Group 1), ethanol (Group 2), ethanol+boric acid (Group 3) and boric acid (Group 4), ( $\mathrm{n}=8)$. Group 1 received isocaloric dexrose solution in $3 \mathrm{ml}$ physiological saline solution (PSS) by gavage as a caloric substitute for alcohol every day for a month. 
Group 2 received $15 \%$ ethanol in PSS at $1.5 \mathrm{~g} / \mathrm{kg} /$ day ethanol for the first week and $30 \%$ ethanol in PSS at $3 \mathrm{~g} / \mathrm{kg} /$ day for second week and $45 \%$ ethanol in PSS at $6 \mathrm{~g} / \mathrm{kg} /$ day for another two weeks through gavage. We have gradually increased the amount of alcohol to prevent the death of the rats and to make the model successful. Group 3 received $15 \%$ ethanol in PSS at $1.5 \mathrm{~g} / \mathrm{kg} / \mathrm{day}$ ethanol +100 $\mathrm{mg} / \mathrm{kg}$ boric acid for the first week and $30 \%$ ethanol in PSS at $3 \mathrm{~g} / \mathrm{kg} /$ day $+100 \mathrm{mg} / \mathrm{kg}$ boric acid for second week and $45 \%$ ethanol in PSS at $6 \mathrm{~g} / \mathrm{kg} / \mathrm{day}+100 \mathrm{mg} / \mathrm{kg}$ boric acid for another two weeks through oral gavage. Group 4 received $100 \mathrm{mg} / \mathrm{kg}$ boric acid in 3ml PSS by oral gavage every day for a month. This dose of boric acid is nontoxic for rodents (Ince et al. 2010; Sogut et al. 2015).

At the end of 30 days, rats were anaesthetized with an intraperitoneal injection of ketamine-xylazine (35-5 mg/kg body weight ) and sacrificed by cervical dislocation at the end of work. Blood was collected from the jugular vein. Liver tissues were excised, frozen in liquid nitrogen and kept at $-80{ }^{\circ} \mathrm{C}$ for biochemical analysis. For histopathological studies, dissected tissues were fixed in neutral formalin for $24-48 \mathrm{~h}$. Routine histopathological procedure was applied after fixation.

\section{Biochemical Measurements}

Blood alcohol concentration (BAC), alanine transaminase (ALT) and aspartate transaminase (AST) measurement: Serum alcohol level were measured by enzymatic method (alcohol dehydrogenase) using commercial Roche kit (Roche Molecular Systems, Branchburg, New Jersey) on Roche-Hitachi Cobas c501 analyzer on the day the rats (group 2 and group 3) were sacrificed. ALT and AST levels of each experimental groups were measurement by enzymatic methods using commercial Roche kit (Roche Molecular Systems, Branchburg, New Jersey) on Roche-Hitachi Cobas c311 analyzer.

Malondialdehyde levels (MDA): At time of analysis, rat liver tissues were weighed and homogenized in an ice-cold $0.15 \mathrm{M} \mathrm{KCl}$ solution using an Ultra Turrax T18 basic homogenizer (IKA, Wilmington, North Carolina). The homogenate was centrifuged at $600 \mathrm{xg}$ for $10 \mathrm{~min}$ at $4^{\circ} \mathrm{C}$ and the supernatants were used to measure MDA levels by the colorimetric reaction of thiobarbituric acid reactive 
substances in the presence of MDA at $532 \mathrm{~nm}$, according to method of Ohkawa et al (Ohkawa et al. 1979). The results were expressed as nmol/mg protein.

Total Sialic acid levels (TSA) : TSA levels in liver homogenate were determined according to the method of Katopodis et al. (Katopodis et al. 1982) which is based on the principle of measuring the color that resorcinol forms with SA at $580 \mathrm{~nm}$. SA values were expressed as $\mathrm{nmol} / \mathrm{mg}$ protein.

Antioxidant enzyme activities in liver homogenates: SOD activity was determined according to the method of Winterbourn et al. (Winterbourn et al. 1975) One unit of SOD expressed in U/mg protein was designated as the amount of enzyme that inhibits the reduction of nitroblue tetrazolium reduction by $50 \%$. CAT activities were calculated using the method of Beutler (Beutler 1982). The reduction in optical density per minute was determined and the enzyme activity was expressed in U/mg protein. GPx activity in $\mathrm{U} / \mathrm{g}$ protein was spectrophotometrically determined at $340 \mathrm{~nm}$ using the methods of Paglia and Valentine (Paglia and Valentine 1967). The protein concentration of homogenates gathered from liver tissues were determined using the Bradford assay.

Caspase-3 activation: Colorimetric caspase-3 measurement kit (Sigma, St. Louis, Missouri) was used to measure caspase-3 activities in supernatant fractions. Results were expressed on $\mu \mathrm{mol} \mathrm{pNA} / \mathrm{minute}$.

TNF-alpha levels (TNF- $\alpha$ ): TNF- $\alpha$ levels were measured using an ELISA assay described for rat TNF- $\alpha$ kit (TNF- $\alpha$ Quantikine ELISA kit, Minneapolis, Minnesota). Results were expressed on pg/mg protein.

\section{Histopathological analysis}

Five $\square \mu \mathrm{m}$ sections were deparaffinized and rehydrated. Slides were stained with haematoxylin and eosin (H\&E) according to routine procedures. Two independent histologists blinded to each other performed all histopathological examinations. Histopathological damage scoring was performed as an inflammations (Kleiner et al. 2005). Each of the criteria was evaluated as (0: absent, 1: mild, 2: 
moderate, 3: severe). Sections were observed under light microscopy and digital photographs were taken (Olympus BX53, Tokyo).

For $T N F-\alpha$ and caspase-3 staining, endogenous peroxidase activity was quenched with $3 \% \mathrm{H}_{2} \mathrm{O}_{2}$ and sections were incubated for overnight at $4^{\circ} \mathrm{C}$ with rabbit polyclonal TNF- $\alpha$ antibody (1:500) (abcam 6671, Cambridge) and caspase-3 (1:1000) (abcam 4051, Cambridge). A streptavidin peroxidase label reagent (abcam 80437, Cambridge) was applied for visualization, using an biotinylated goat anti-rabbit antibodies (Invitrogen 859043, Grand Island, New York) and diaminobenzidine (DAB) staining (abcam ab8043, Cambridge). Hepatocytes stained with antibodies against TNF- $\alpha$ and caspase-3 were evaluated by using an Olympus microscope on 5 different fields at x200 magnification by two blinder observers. The HSCORE was calculated using the equation: HSCORE $=$ SPi $(i+1)$, where $i$ was intensity of staining with a value of 1 (weak), 2 (moderate), or 3 (strong) and Pi was the percentage of stained tissues for each intensity (De los Santos et al. 1996).

For Terminal deoxynucleotidyl transferase-mediated dUTP nick end labeling (TUNEL) staining, slides were stained with the reagents supplied by Apoptosis Detection Kit (Millipore ApopTag S7101, Billerica, Massachusetts). Then DAB chromogen was applied. Methyl green was used as counterstaining. For negative control, TdT was omitted from the reaction mixture. Marked apoptotic cells were counted under high-powerfields $(\times 400)$ with a light microscope (Leica DM2500, Wetzlar) (Erdogan et al. 2015). All TUNEL positive cells in 15 different unit areas were counted on the crosssections by a blinded researcher. Average cell per unit area number for each set of specimens in each group was calculated and compared.

Statistical analysis: SPSS software, version 22.0 for Windows (SPSS, Inc., Chicago, Illinois) was used for the statistical analysis of biochemical and histopathological data. To data that show compliance with normal distribution, one-wayANOVA was applied, while to data that normal distribution does not fit, the Kruskal-Wallis test was applied. Results are presented as mean \pm standard deviation and $\mathrm{P}<0.05$ was considered to indicate a statistically significant result. UNISTAT 5.0 for Windows (Istanbul University, Istanbul) was used for the statistical analysis of TUNEL method. 
Apoptotic cell counts of groups were compared using the Kruskal-Wallis one-way ANOVA and Tukey-Kramer tests. $\mathrm{P}<0.05$ was considered as statistically significant.

\section{RESULTS}

\section{Biochemical Results (Table 1)}

Blood alcohol Concentration (BAC; $\mathrm{mg} / \mathrm{dl}$ ) in the ethanol group was significant increased compared with the ethanol+boric acid group $(\mathrm{P}<0.01)$. ALT activity (U/L) in the control group was significantly decreased compared with the ethanol group and ethanol+boric acid group $(\mathrm{P}<0.001$ and $\mathrm{P}<0.01$, respectively). The ALT levels of the ethanol group was significant higher than that of the ethanol+boric acid group and boric acid group ( $\mathrm{P}<0.05$ and $\mathrm{P}<0.001$, respectively). ALT levels in the ethanol+boric acid was significantly increased compared with the boric acid group $(\mathrm{P}<0.001)$. No statistically significant differences in AST activities (U/L) were identified among the groups. MDA levels (nmol/mg protein) in the ethanol group was significantly increased compared with the control levels $(\mathrm{P}<0.05)$. MDA levels in ethanol+boric acid was significantly decreased compared with the ethanol group $(\mathrm{P}<0.01)$. TSA levels $(\mathrm{nmol} / \mathrm{mg}$ protein) of the ethanol group was significant higher than that of the control group and the ethanol+boric acid group and boric acid group $(\mathrm{P}<0.01$, $\mathrm{P}<0.001, \mathrm{P}<0.001$, respectively). Administration of ethanol decreased the SOD activities $(\mathrm{U} / \mathrm{mg}$ protein) significantly as compared with the control group and the ethanol+boric acid group and boric acid group $(\mathrm{P}<0.01)$. No statistically significant differences in CAT activities (U/mg protein) were identified among the groups. GPx activity (U/mg protein) in the control group was increased compared with the ethanol and ethanol+boric acid $(\mathrm{P}<0.001)$. GPx activity in the ethanol group was significantly decreased compared with the ethanol+boric acid and boric acid $(\mathrm{P}<0.05, \mathrm{P}<0.001$, respectively). GPx activity in the boric acid group was significantly increased compared with the ethanol+boric acid $(\mathrm{P}<0.05)$. Caspase-3 enzyme activity ( $\mu \mathrm{mol} \mathrm{pNA} /$ minute) in the ethanol group increased significantly much higher in comparison with the ethanol+boric acid group $(\mathrm{P}<0.01)$. TNF- 
$\boldsymbol{\alpha}$ levels (pg/mg protein) of the ethanol group was significant higher than that of the control and the ethanol+boric acid and boric acid ( $\mathrm{P}<0.001, \mathrm{P}<0.01, \mathrm{P}<0.01$, respectively).

\section{Histopathological Results (Table 2)}

Inflamation with $\mathbf{H} \& \mathbf{E}$, according to data, inflammation rate was quite high in ethanol group compared to ethanol+boric acid group and this increase was significant $(\mathrm{P}<0.05)$ (Figure 1). When these scoring data were analyzed statistically, Caspase-3 activities of ethanol group were found to be significantly increased compared to control group, ethanol+boric acid group and boric acid group ( $\mathrm{P}<0.01, \mathrm{P}<0.01$ and $\mathrm{P}<0,05$, respectively) (Figure 2). TNF- $\boldsymbol{\alpha}$ levels in the ethanol group was significantly increased compared with the control group and ethanol+boric acid group $(\mathrm{P}<0.001)$ (Figure 3). TUNEL positive cell of the control group was significant decreased lower than that of the ethanol and the ethanol+boric acid and boric acid $(\mathrm{P}<0.001)$. TUNEL positive cell of the boric acid group was significant decreased lower than ethanol and ethanol+boric acid group $(\mathrm{P}<0.001)$ (Figure 4).

\section{DISCUSSION}

In this study, we investigated the possible preventive effects of boric acid administration on oxidative damage and apoptosis related to chronic ethanol consumption. While human body produces very few amounts of ROS during metabolic reactions, excessive alcohol consumption leads to intensive ROS synthesis which causes impairments in cellular molecules such as lipid, proteins and nucleotides (Tuma and Casey 2003). In our study, levels of MDA, a lipid peroxidation end product, and TSA, which is a terminal component on un reductated ends of glycolipids and glycoproteins, were significantly increased. Parallel with our results, alcohol consumption was previously shown to increase MDA and TSA leves in liver cells (Kanbak et al. 2001; Romppanen et al. 2002). Ethanol+boric acid treatment has significantly decreased alcohol-induced membrane damage as 
indicated by reduced MDA and TSA levels in our study. Previos studies also showed that boric acid treatment reduced lipid peroxidation and membrane damage (Ince et al. 2010; Sogut et al. 2015).

Furthermore, BA is prevented from cyclophosphamide-induced and carbon tetrachloride-induced oxidative stress (Ince et al. 2012; Ince et al. 2014).

Various defence mechanisms are present to cope with increased ROS production and cellular damage related to alcohol consumption. Intracellular antioxidants SOD, CAT and GPx are part of this defence system (Brocardo et al. 2011) . Chronic alcohol consumption was shown to increase oxidative stress while decrease intracellular antioxidant levels (Sogut et al. 2015). Similarly, intracellular antioxidant levels were significantly reduced in alcohol group in our study. On the other hand, SOD and GPx activities were increased significantly while catalase activities were not increased significantly in ethanol+boric acid group of our study. Previous studies also showed that boric acid treatment increased SOD, CAT and GSH activities (Coban et al. 2015; Ince et al. 2012). Boric acid is involved in cellular membrane functions although its antioxidant mechanisms are not clearly defined yet (Hunter 2005; Nielsen 2008). It was previously shown that $100 \mathrm{mg} / \mathrm{kg}$ boric acid supplementation decreased lipid peroxidation while increased antioxidant defence levels (Ince et al. 2010; Sogut et al. 2015). Boric acid (BA) is a fundamental element for plants, humans, and animals to metabolic processes (Hunter 2005; Nielsen 2008). Boric acid contains $17.48 \%$ boron. When boron is taken orally, it enters the blood stream and its urinary excretion rate is $\sim 100 \%$. Boron has not accretion in the human body (Tepedelen et al. 2016). Existing data indicated that the oral $\mathrm{LD}_{50}$ values for boric acid in mice and rats are in the range of about $400-700 \mathrm{mg}$ of boron per $\mathrm{kg}$ of body weight. No toxic effects were observed in short term (less than one month) chronic boric acid (100 mg/kg boric acid) supplementation in rodents (Weir and Fisher 1972). Furthermore, the same dose of boric acid has been used in many studies to reduce oxidative damage (Ince et al. 2010; Kizilay et al. 2016; Sogut et al. 2015). 
We hypothesize that possible mechanism of boric acid administration is increasing SAM (S-adenosyl methinonine) levels which causes the prevention of alcohol related lipid peroxidaiton. As a Lewis acid, boric acid may form complexes through its hydroxyl groups with several biological compounds (Hunter 2005; Nielsen 2008). Boric acid has a high affinity to SAM which acts as a methyl donour in pathways like transsulfuration and polyamine synthesis (Nielsen 2009). Previous studies revealed that chronic alcohol consumption decreased SAM levels while increase SAH (S-Adenosyl homocycsteine) levels and subsequently improved SAM/SAH ratio which is an indicator of methylation capacity (Stickel et al. 2000). In another study, boron deficiency decreased SAM levels while increased homocycsteine levels (Hunter 2005). Similar to these studies, boric acid supplementation increased SAM/SAH ratio and mediated cellular membrane functions in our study indicated by the decreases in MDA and sialic acid levels which are markers for membrane integrity distruption.

Several markers for alcoholic liver disease and nonalcoholic steatohepatitis have been studied e.g. AST, ALT, carbohydrate deficient transferrin (CDT), gamma glutamyl transferase (GGT) and tissue polypeptide-specific antigen (cytokeratin; CK-18, CK-19) (Gonzalez-Quintela et al. 2006; Nyblom et al. 2004). Alcohol administration caused statistically significant and non significant elevations in liver ALT and AST levels respectively. Increased serum aminotransferase activities are important markers for liver related diseases. Blood alcohol leves were also measured in our study. Blood alcohol concentrations of $100 \mathrm{mg} / \mathrm{dl}$ and above are considered toxic doses (Gentilello et al. 1999). Acute or chronic $200 \mathrm{mg} / \mathrm{dl}$ blood alcohol concentration is reported to decrease cell proliferation and promote cell death (He et al. 2005). Mean blood alcohol concentration of $191,1 \pm 13,53 \mathrm{mg} / \mathrm{dl}$ in our study caused liver damage which is parallel to previous studies. Blood alcohol concentrations were significantly reduced in ethanol+boric acid group which may be attributed to inhibitor effect of boric acid on aldehyde dehydrogenase enzyme (Hunter 2005; Nielsen 2008). 
Alcohol triggers ROS overproduction and causes hepatic apoptosis through oxidative stress. Ethanol induces apoptosis via intrinsic and extrinsic caspase related pathways and also caspase independent pathways (Chandramoorthy et al. 2012; Manzo-Avalos and Saavedra-Molina 2010; Mooney et al. 2006). Our biochemical and histopathological results showed that caspase-3, TNF- $\alpha$, inflammation but not DNA fragmentation, were significantly decreased in ethanol+boric acid administration groups. Inflammatory agents like ethanol may induce necrosis, apoptosis and distruption in hepatocytes. Production of extracellular matrix proteins may induce fibrosis and activate hepatic stellate cells (Kupffer Cells) (Dai et al. 2003). This activation induces liver damage and may also cause overproduction of extracellular matrix proteins, forming collagen type one. Alcohol adiministration was shown to increase the sensitivity of Kupffer Cells and the production inflammatory cytokines (Dai et al. 2003) which further incerases TNF- $\alpha$ and ROS synthesis (Nagai et al. 2002).

Our results are similar to the previous studies which show that ethanol can trigger apoptosis (Cohen et al. 2009; Sogut et al. 2017). Tang et al. also demonstrated that proper doses of boric acid (160 mg/L most) prevents apoptosis and brain development damage in ostrich chick brains (Tang et al. 2016). ROS contributes inflammation process. GSH is an important agent against protecting cellular redox balance against ROS related oxidative stress. Anti reheumatoid drug usage increases GSH levels in patient with arthritis. There is a special association between TNF- $\alpha$ levels and GSH (Toborek et al. 1995). It was observed that boron administration reduced oxidative damage by increasing glutathione reserves which neutralize oxidative agents (Cao et al. 2008). In addition to these, administration of boric acid increases the levels of GSH level, thereby reserving the toxic effects of malathion (Coban et al. 2015). In an experimental rat model of infant necrotic enterocolitis, boric acid administration elevated antioxidant levels by preventing the depletion of GSH reserves (Yazici et al. 2014). Also, boric acid treatment reduced prostate cancer cell proliferation by decreasing intracellular $\mathrm{Ca}^{++}$reserves and signalling which are important in apoptosome formation (Henderson et al. 2009; Scorei et al. 2008). Boric acid may have a possible indirectly preventive effect on apoptosis. Boric acid may increase anti-oxidant levels (probably by preventing GSH depletion) and limits inflammatory 
processes by decrasing intracelleular ROS and $\mathrm{Ca}^{++}$levels and finally, reduced TNF- $\alpha$ and ROS levels prevent apoptotic cell death.

In conclusion, mechanisms of alcoholic liver disease are not fully revealed and also mechanisms of boric acid are still being studied. We think that boric acid increase antioxidant, GSH and SAM levels and therefore has preventive effect on oxidative damage, inflammatory processes, and apoptosis. According to our study, we propose that further reserach is required on the dose related effects of boric acid on SAH (SAM) and GSH levels.

Acknowledgements: This work was supported by TUBITAK 113S546 project. The authors declare that there are no conflicts of interest. The authors thank Esra Cikler Dulger, Melis Savasan Sogut, Albena Gayef, Aysegul Oglakci and Sakir Sekmen for their efforts in this study. 


\section{REFERENCES}

Beutler, E. 1982. Catalase. In In Red Cell Metabolism. A Manual of Biochemical Methods. Edited by E. Beutler. Grune and Stratton, New York. pp. 105-106.

Brocardo, P.S., Gil-Mohapel, J., and Christie, B.R. 2011. The role of oxidative stress in fetal alcohol spectrum disorders. Brain Res Rev 67(1-2): 209-225. doi: S0165-0173(11)00014-2 [pii] 10.1016/j.brainresrev.2011.02.001.

Cao, J., Jiang, L., Zhang, X., Yao, X., Geng, C., Xue, X., and Zhong, L. 2008. Boric acid inhibits LPSinduced TNF-alpha formation through a thiol-dependent mechanism in THP-1 cells. J Trace Elem Med Biol 22(3): 189-195. doi: S0946-672X(08)00036-9 [pii]

10.1016/j.jtemb.2008.03.005.

Chandramoorthy, H.C.K., Mallilankaraman, K., Madesh, M. 2012. Ethanol-induced mitochondrial induction of cell death-patways explored. In Trends in alcoholic liver disease research-clinical and scientific aspect. Edited by S. Ichiro. InTech, Rijeka. pp. 79-90.

Coban, F.K., Ince, S., Kucukkurt, I., Demirel, H.H., and Hazman, O. 2015. Boron attenuates malathion-induced oxidative stress and acetylcholinesterase inhibition in rats. Drug Chem Toxicol 38(4): 391-399. doi: 10.3109/01480545.2014.974109.

Cohen, J.I., Roychowdhury, S., DiBello, P.M., Jacobsen, D.W., and Nagy, L.E. 2009. Exogenous thioredoxin prevents ethanol-induced oxidative damage and apoptosis in mouse liver. Hepatology 49(5): 1709-1717. doi: 10.1002/hep.22837.

Dai, L.L., Gong, J.P., Zuo, G.Q., Wu, C.X., Shi, Y.J., Li, X.H., Peng, Y., Deng, W., Li, S.W., and Liu, C.A. 2003. Synthesis of endotoxin receptor CD14 protein in Kupffer cells and its role in alcoholinduced liver disease. World J Gastroenterol 9(3): 622-626.

De los Santos, M.J., Mercader, A., Frances, A., Portoles, E., Remohi, J., Pellicer, A., and Simon, C. 1996. Role of endometrial factors in regulating secretion of components of the immunoreactive human embryonic interleukin-1 system during embryonic development. Biol Reprod 54(3): 563-574.

Erdogan, H., Tuncdemir, M., Kelten, B., Akdemir, O., Karaoglan, A., and Tasdemiroglu, E. 2015. The Effects of Difumarate Salt S-15176 after Spinal Cord Injury in Rats. J Korean Neurosurg Soc 57(6): 445-454. doi: 10.3340/jkns.2015.57.6.445.

Gentilello, L.M., Villaveces, A., Ries, R.R., Nason, K.S., Daranciang, E., Donovan, D.M., Copass, M., Jurkovich, G.J., and Rivara, F.P. 1999. Detection of acute alcohol intoxication and chronic alcohol dependence by trauma center staff. J Trauma 47(6): 1131-1135; discussion 1135-1139.

Gonzalez-Quintela, A., Garcia, J., Campos, J., Perez, L.F., Alende, M.R., Otero, E., Abdulkader, I., and Tome, S. 2006. Serum cytokeratins in alcoholic liver disease: contrasting levels of cytokeratin-18 and cytokeratin-19. Alcohol 38(1): 45-49. doi: S0741-8329(06)00020-6 [pii]

10.1016/j.alcohol.2006.01.003.

He, J., Nixon, K., Shetty, A.K., and Crews, F.T. 2005. Chronic alcohol exposure reduces hippocampal neurogenesis and dendritic growth of newborn neurons. Eur J Neurosci 21(10): 2711-2720. doi: EJN4120 [pii]

10.1111/j.1460-9568.2005.04120.x.

Henderson, K., Stella, S.L., Kobylewski, S., and Eckhert, C.D. 2009. Receptor activated Ca(2+) release is inhibited by boric acid in prostate cancer cells. PLoS One 4(6): e6009. doi: 10.1371/journal.pone.0006009. 
Hunter, C. 2005. Boron. In In Encyclopedia of Dietary Supplements. Edited by B.M. Coates PM, Cragg GM, Levine M, Moss J and White JD. Marcel Dekker, New York. pp. 55-65.

Ince, S., Keles, H., Erdogan, M., Hazman, O., and Kucukkurt, I. 2012. Protective effect of boric acid against carbon tetrachloride-induced hepatotoxicity in mice. Drug Chem Toxicol 35(3): 285-292. doi: 10.3109/01480545.2011.607825.

Ince, S., Kucukkurt, I., Cigerci, I.H., Fatih Fidan, A., and Eryavuz, A. 2010. The effects of dietary boric acid and borax supplementation on lipid peroxidation, antioxidant activity, and DNA damage in rats. J Trace Elem Med Biol 24(3): 161-164. doi: S0946-672X(10)00004-0 [pii]

10.1016/j.jtemb.2010.01.003.

Ince, S., Kucukkurt, I., Demirel, H.H., Acaroz, D.A., Akbel, E., and Cigerci, I.H. 2014. Protective effects of boron on cyclophosphamide induced lipid peroxidation and genotoxicity in rats. Chemosphere 108: 197-204. doi: S0045-6535(14)00104-0 [pii]

10.1016/j.chemosphere.2014.01.038.

Kanbak, G., Inal, M., and Baycu, C. 2001. Ethanol-induced hepatotoxicity and protective effect of betaine. Cell Biochem Funct 19(4): 281-285. doi: 10.1002/cbf.926 [pii]

10.1002/cbf.926.

Katopodis, N., Hirshaut, Y., Geller, N.L., and Stock, C.C. 1982. Lipid-associated sialic acid test for the detection of human cancer. Cancer Res 42(12): 5270-5275.

Kizilay, Z., Erken, H.A., Cetin, N.K., Aktas, S., Abas, B.I., and Yilmaz, A. 2016. Boric acid reduces axonal and myelin damage in experimental sciatic nerve injury. Neural Regen Res 11(10): 1660-1665. doi: $10.4103 / 1673-5374.193247$

NRR-11-1660 [pii].

Kleiner, D.E., Brunt, E.M., Van Natta, M., Behling, C., Contos, M.J., Cummings, O.W., Ferrell, L.D., Liu, Y.C., Torbenson, M.S., Unalp-Arida, A., Yeh, M., McCullough, A.J., and Sanyal, A.J. 2005. Design and validation of a histological scoring system for nonalcoholic fatty liver disease. Hepatology 41(6): 1313-1321. doi: 10.1002/hep.20701.

Lieber, C.S. 1997. Ethanol metabolism, cirrhosis and alcoholism. Clin Chim Acta 257(1): 59-84. doi: S0009898196064340 [pii].

Manzo-Avalos, S., and Saavedra-Molina, A. 2010. Cellular and mitochondrial effects of alcohol consumption. Int J Environ Res Public Health 7(12): 4281-4304. doi: 10.3390/ijerph7124281.

Mooney, S.M., Miller, M.W., Henderson, G.I. 2006. Intracellular events in ethanol-induced neuronal death. In Brain Development Normal Processes and the effects of alcohol and nicotine. Edited by M. MW. Oxford University Press, New York. pp. 267-278.

Nagai, H., Matsumaru, K., Feng, G., and Kaplowitz, N. 2002. Reduced glutathione depletion causes necrosis and sensitization to tumor necrosis factor-alpha-induced apoptosis in cultured mouse hepatocytes. Hepatology 36(1): 55-64. doi: S027091390200006X [pii]

10.1053/jhep.2002.33995.

Nielsen, F.H. 2008. Is boron nutritionally relevant? Nutr Rev 66(4): 183-191. doi: NURE023 [pii] $10.1111 / \mathrm{j} .1753-4887.2008 .00023 . x$.

Nielsen, F.H. 2009. Boron deprivation decreases liver S-adenosylmethionine and spermidine and increases plasma homocysteine and cysteine in rats. J Trace Elem Med Biol 23(3): 204-213. doi: S0946-672X(09)00029-7 [pii] 
10.1016/j.jtemb.2009.03.001.

Nyblom, H., Berggren, U., Balldin, J., and Olsson, R. 2004. High AST/ALT ratio may indicate advanced alcoholic liver disease rather than heavy drinking. Alcohol Alcohol 39(4): 336-339. doi: 10.1093/alcalc/agh074

39/4/336 [pii].

Ohkawa, H., Ohishi, N., and Yagi, K. 1979. Assay for lipid peroxides in animal tissues by thiobarbituric acid reaction. Anal Biochem 95(2): 351-358.

Paglia, D.E., and Valentine, W.N. 1967. Studies on the quantitative and qualitative characterization of erythrocyte glutathione peroxidase. J Lab Clin Med 70(1): 158-169. doi: 0022-2143(67)90076-5 [pii].

Poschl, G., and Seitz, H.K. 2004. Alcohol and cancer. Alcohol Alcohol 39(3): 155-165.

Romppanen, J., Punnonen, K., Anttila, P., Jakobsson, T., Blake, J., and Niemela, O. 2002. Serum sialic acid as a marker of alcohol consumption: effect of liver disease and heavy drinking. Alcohol Clin Exp Res 26(8): 1234-1238. doi: 10.1097/01.ALC.0000025887.70136.4E.

Scorei, R., Ciubar, R., Ciofrangeanu, C.M., Mitran, V., Cimpean, A., and Iordachescu, D. 2008. Comparative effects of boric acid and calcium fructoborate on breast cancer cells. Biol Trace Elem Res 122(3): 197-205. doi: 10.1007/s12011-007-8081-8.

Sogut, I., Oglakci, A., Kartkaya, K., Ol, K.K., Sogut, M.S., Kanbak, G., and Inal, M.E. 2015. Effect of boric acid on oxidative stress in rats with fetal alcohol syndrome. Exp Ther Med 9(3): 1023-1027. doi: 10.3892/etm.2014.2164

etm-09-03-1023 [pii].

Sogut, I., Uysal, O., Oglakci, A., Yucel, F., Kartkaya, K., and Kanbak, G. 2017. Prenatal alcoholinduced neuroapoptosis in rat brain cerebral cortex: protective effect of folic acid and betaine. Childs Nerv Syst 33(3): 407-417. doi: 10.1007/s00381-016-3309-6

10.1007/s00381-016-3309-6 [pii].

Stickel, F., Choi, S.W., Kim, Y.I., Bagley, P.J., Seitz, H.K., Russell, R.M., Selhub, J., and Mason, J.B. 2000. Effect of chronic alcohol consumption on total plasma homocysteine level in rats. Alcohol Clin Exp Res 24(3): 259-264.

Tang, J., Zheng, X.T., Xiao, K., Wang, K.L., Wang, J., Wang, Y.X., Wang, K., Wang, W., Lu, S., Yang, K.L., Sun, P.P., Khaliq, H., Zhong, J., and Peng, K.M. 2016. Effect of Boric Acid Supplementation on the Expression of BDNF in African Ostrich Chick Brain. Biol Trace Elem Res 170(1): 208-215. doi: 10.1007/s12011-015-0428-y

10.1007/s12011-015-0428-y [pii].

Tepedelen, B.E., Soya, E., and Korkmaz, M. 2016. Boric Acid Reduces the Formation of DNA Double Strand Breaks and Accelerates Wound Healing Process. Biol Trace Elem Res 174(2): 309-318. doi: 10.1007/s12011-016-0729-9

10.1007/s12011-016-0729-9 [pii].

Toborek, M., Barger, S.W., Mattson, M.P., McClain, C.J., and Hennig, B. 1995. Role of glutathione redox cycle in TNF-alpha-mediated endothelial cell dysfunction. Atherosclerosis 117(2): 179-188. doi: 0021-9150(95)05568-H [pii].

Tuma, D.J., and Casey, C.A. 2003. Dangerous byproducts of alcohol breakdown--focus on adducts. Alcohol Res Health 27(4): 285-290. 
Ustundag, A., Behm, C., Follmann, W., Duydu, Y., and Degen, G.H. 2014. Protective effect of boric acid on lead- and cadmium-induced genotoxicity in V79 cells. Arch Toxicol 88(6): 1281-1289. doi: 10.1007/s00204-014-1235-5.

Weir, R.J., Jr., and Fisher, R.S. 1972. Toxicologic studies on borax and boric acid. Toxicol Appl Pharmacol 23(3): 351-364.

WHO. 2011. Global status report on alcohol and health 9789241564151

Winterbourn, C.C., Hawkins, R.E., Brian, M., and Carrell, R.W. 1975. The estimation of red cell superoxide dismutase activity. J Lab Clin Med 85(2): 337-341. doi: 0022-2143(75)90439-4 [pii].

Yazici, S., Aksit, H., Korkut, O., Sunay, B., and Celik, T. 2014. Effects of boric acid and 2aminoethoxydiphenyl borate on necrotizing enterocolitis. J Pediatr Gastroenterol Nutr 58(1): 61-67. doi: 10.1097/MPG.0b013e3182a7e02b. 
Table 1: Blood alcohol concentration (BAC), alanine transaminase activities (ALT), aspartate transaminase activities (AST), malondialdehyde levels (MDA), total sialic acid levels (TSA), superoxide dismutase activities (SOD), catalase activities (CAT), glutathione peroxidase activities (GPx), caspase-3 activities (Cas-3), tumor necrosis factor-alpha levels (TNF- $\alpha$ ), in serum and liver homogenate of control, ethanol, ethanol+boric acid and boric acid groups.

\begin{tabular}{|c|c|c|c|c|c|}
\hline $\begin{array}{l}\text { Groups } \rightarrow \\
\text { Biochemical Parameters }\end{array}$ & $\begin{array}{l}\text { Group } 1 \\
\text { Control }\end{array}$ & $\begin{array}{l}\text { Group 2 } \\
\text { Ethanol }\end{array}$ & $\begin{array}{l}\text { Group } 3 \\
\text { Ethanol+Boric } \\
\text { acid }\end{array}$ & $\begin{array}{l}\text { Group } 4 \\
\text { Boric acid }\end{array}$ & $\mathbf{P}$ \\
\hline BAC (mg/dl) & & $191 \pm 13.53$ & $127 \pm 6.67$ & & $2-3^{* *}$ \\
\hline $\operatorname{ALT}(\mathbf{U} / \mathbf{L})$ & $53.83 \pm 1.1$ & $66.5 \pm 0.96$ & $60.9 \pm 1.75$ & $52.06 \pm 1.71$ & $\begin{array}{l}1-2^{* * *}, \quad 1-3^{* *}, \\
2-3^{*}, \\
3-4^{* * *}\end{array}$ \\
\hline AST (U/L) & $162.9 \pm 13.03$ & $191.5 \pm 11.77$ & $174.0 \pm 10.53$ & $165.7 \pm 15.79$ & ns \\
\hline MDA (nmol/dl) & $4.95 \pm 0.21$ & $6.08 \pm 0.29$ & $4.87 \pm 0.17$ & $5.30 \pm 0.25$ & $1-2^{*}, 2-3^{* *}$ \\
\hline TSA ( nmol/dl) & $99.37 \pm 2.35$ & $125.5 \pm 5.11$ & $90.25 \pm 4.28$ & $96.0 \pm 4.46$ & $\begin{array}{l}1-2^{* *}, \quad 2-3^{* * *}, \\
2-4^{* * *}\end{array}$ \\
\hline SOD (U/mg protein) & $7.05 \pm 0.36$ & $4.33 \pm 0.17$ & $6.76 \pm 0.69$ & $6.92 \pm 0.59$ & $\begin{array}{l}1-2^{* *}, \quad 2-3^{* *}, \\
2-4^{* *}\end{array}$ \\
\hline CAT (U/mg protein) & $138 \pm 21.7$ & $88.8 \pm 10.0$ & $135.7 \pm 12.8$ & $132.5 \pm 12.1$ & ns \\
\hline GPx (U/mg protein) & $42.6 \pm 1.4$ & $25.6 \pm 1.6$ & $33 \pm 1.3$ & $40.1 \pm 1.6$ & $\begin{array}{l}1-2^{* * *}, \quad 1-3^{* * *}, \\
2-3^{*}, \quad 2-4^{* * *}, \\
3-4^{*}\end{array}$ \\
\hline Cas-3 ( $\mu \mathrm{mol}$ pNA/minute) & $117 \pm 1.0$ & $135.7 \pm 6.0$ & $105 \pm 10.2$ & $113.7 \pm 1.2$ & $2-3^{* *}$ \\
\hline TNF- $\alpha$ (pg/g protein) & $550 \pm 28.8$ & $1113 \pm 57.8$ & $735 \pm 72.17$ & $725 \pm 14.43$ & $\begin{array}{l}1-2 * * *, 2-3 * * \\
2-4 * *\end{array}$ \\
\hline
\end{tabular}

non significant (ns), $\left({ }^{*} \mathrm{p}<0.05,{ }^{* *} \mathrm{p}<0.01,{ }^{* * *} \mathrm{p}<0.001\right)$ 
Table 2: Haematoxylin and eosin storing (H\&E), caspase-3 immunoreactivities (Cas-3), tumor necrosis factor-alpha immunoreactivities (TNF- $\alpha$ ) and TUNEL positive cells in liver tissue sections of control, ethanol, ethanol+boric acid and boric acid group.

\begin{tabular}{|l|l|l|l|l|l|}
\hline $\begin{array}{l}\text { Groups } \rightarrow \\
\text { Histological } \\
\text { Parameters }\end{array}$ & $\begin{array}{l}\text { Group 1 } \\
\text { Control }\end{array}$ & $\begin{array}{l}\text { Group 2 } \\
\text { Ethanol }\end{array}$ & $\begin{array}{l}\text { Group 3 } \\
\text { Ethanol+Boric } \\
\text { acid }\end{array}$ & $\begin{array}{l}\text { Group 4 } \\
\text { Boric acid }\end{array}$ & P \\
\hline H\&E & $0.21 \pm 0.43$ & $0.39 \pm 0.72$ & $0.17 \pm 0.56$ & $0.25 \pm 0.60$ & $2-3^{*}$ \\
\hline Cas-3 & $1.66 \pm 0.80$ & $2.52 \pm 1.39$ & $1.80 \pm 1.66$ & $1.83 \pm 1.26$ & $\begin{array}{l}1-2^{* *}, \quad 2-3^{* *}, \\
2-4^{*}\end{array}$ \\
\hline TNF-a & $0.79 \pm 0.92$ & $2.02 \pm 1.82$ & $0.94 \pm 0.39$ & $1.43 \pm 1.02$ & $1-2^{* * *}, 2-3^{* * *}$ \\
\hline TUNEL positive cell & $1.0 \pm 0.09$ & $2.14 \pm 0.07$ & $2.01 \pm 0.06$ & $1.70 \pm 0.10$ & $\begin{array}{l}1-2^{* * *}, 1-3^{* * *}, \\
1-4^{* * *}, 2-4^{* * *}, \\
3-4^{* * *}\end{array}$ \\
\hline
\end{tabular}

$\left({ }^{*} \mathrm{p}<0.05,{ }^{* *} \mathrm{p}<0.01,{ }^{* * *} \mathrm{p}<0.001\right)$ 


\section{Legends of Figures}

Figure 1. H\&E staining of liver tissue sample. Control; Group 1 (A), Ethanol; Group 2 (B) lymphocyte clusters in liver periportal space $(\boldsymbol{\Delta})$ vacuolization in hepatocytes $(\rightarrow)$, Ethanol+Boric acid; Group 3 (C), Boric acid; Group 4 (D) relatively decreased lymphocyte cluster in liver periportal space, (VC: vena centralis, bar: $50 \mu \mathrm{m}$ )

Figure 2. Caspase-3 immunohistochemical staining of the liver tissue sample. Few number marked cells in Control; Group 1 (A), a great number marked cluster in liver periportal space of Ethanol; Group 2 (B), A few number marked cells in liver periportal space of Ethanol+Boric acid; Group 3 (C), few number marked cells in Boric acid; Group 4 (D). (VC: vena centralis, bar: $20 \mu \mathrm{m}$, Dark Brown cells are caspase-3 positive $(\boldsymbol{\Lambda})$.

Figure 3. TNF- $\alpha$ immunohistochemical staining of the liver tissue sample. Few number marked cells in Control; Group 1 (A), multiple marked cells in Ethanol; Group 2 (B), Few number marked cells in Ethanol+Boric acid; Group 3 (C), a few number marked cell in Boric acid; Group 4 (D). (VC: vena centralis, bar: $20 \mu \mathrm{m}$, Dark Brown cells are TNF- $\alpha$ positive ( $\mathbf{\Lambda})$.

Figure 4. TUNEL staining of liver tissue samples. Control; Group 1 (A), Ethanol; Group 2 (B), Ethanol+Boric acid; Group 3 (C), Boric acid; Group 4 (D), (arrows: apoptotic cells, bar: 40 $\mu \mathrm{m}, \mathrm{cv}$ : central vein). 

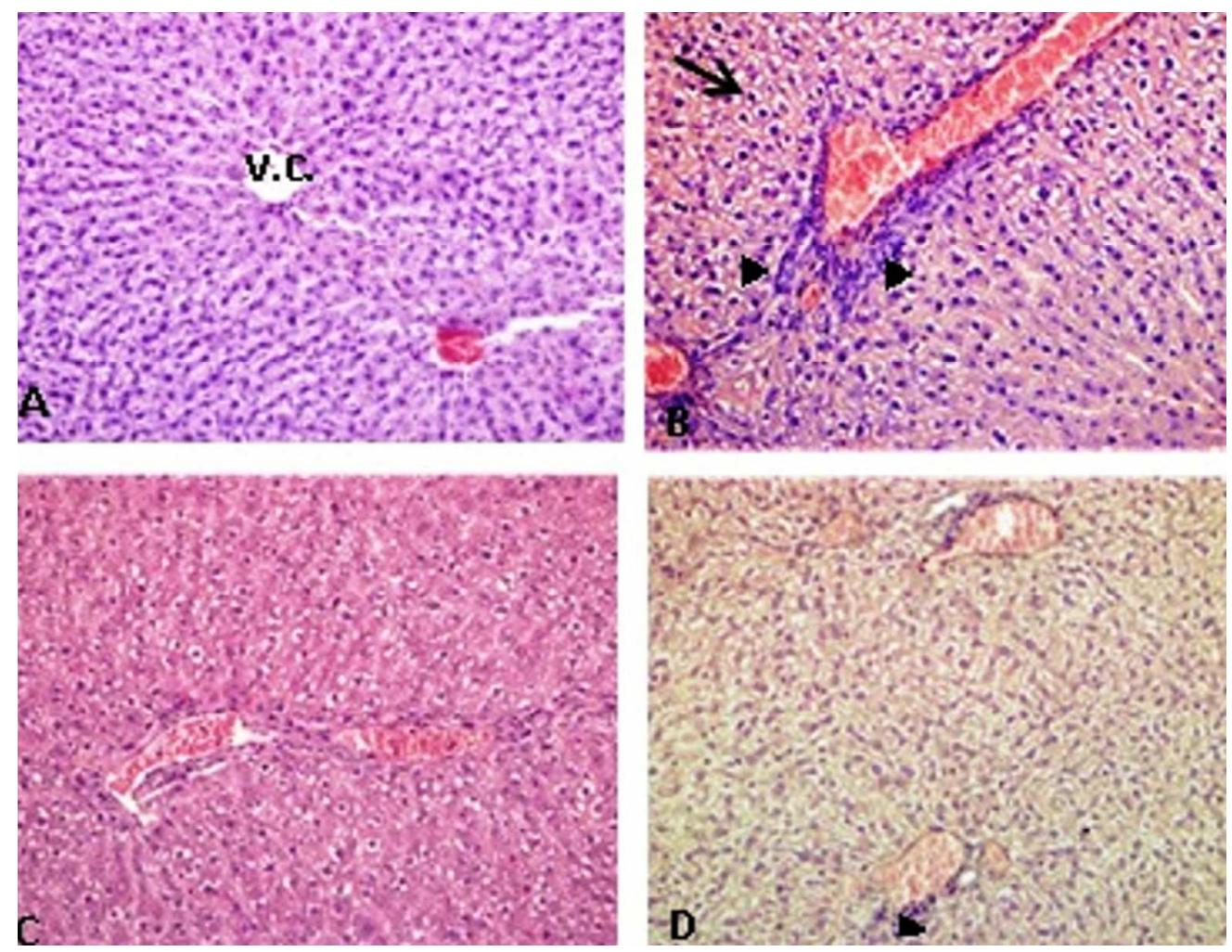

Figure 1

$279 \times 215 \mathrm{~mm}(300 \times 300 \mathrm{DPI})$

https://mc06.manuscriptcentral.com/cjpp-pubs 

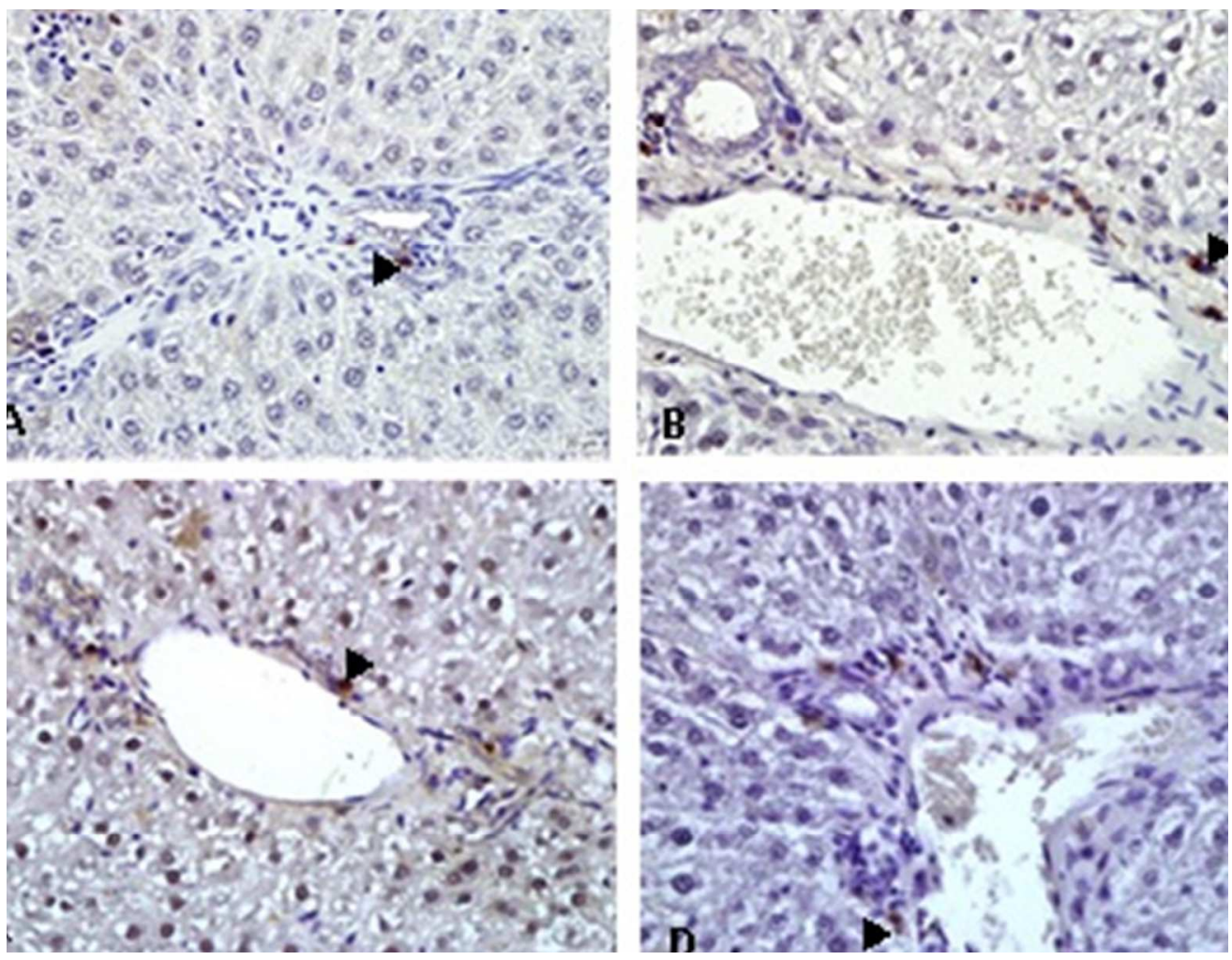

Figure 2

$279 \times 215 \mathrm{~mm}(300 \times 300 \mathrm{DPI})$ 

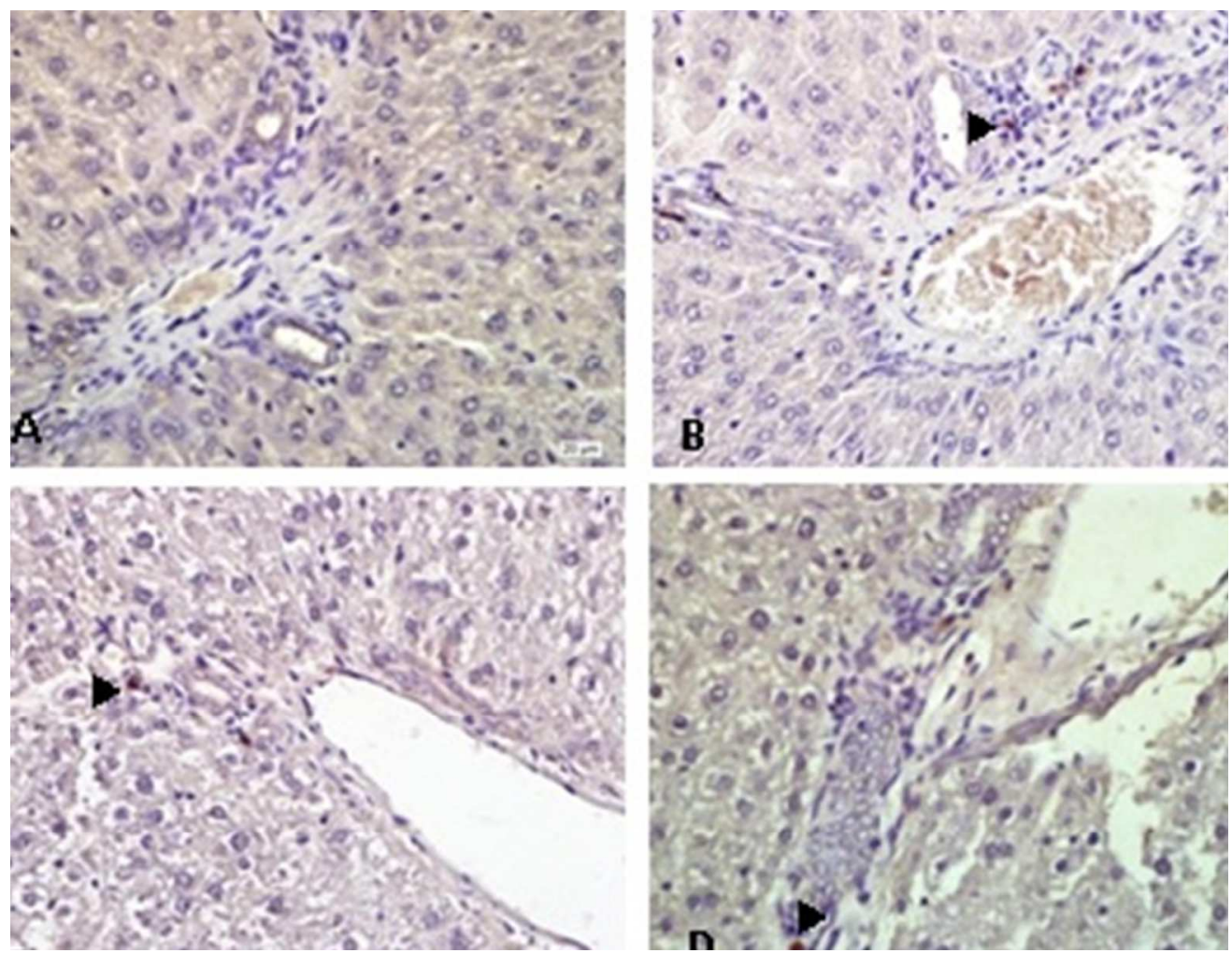

Figure 3

$279 \times 215 \mathrm{~mm}(300 \times 300 \mathrm{DPI})$ 

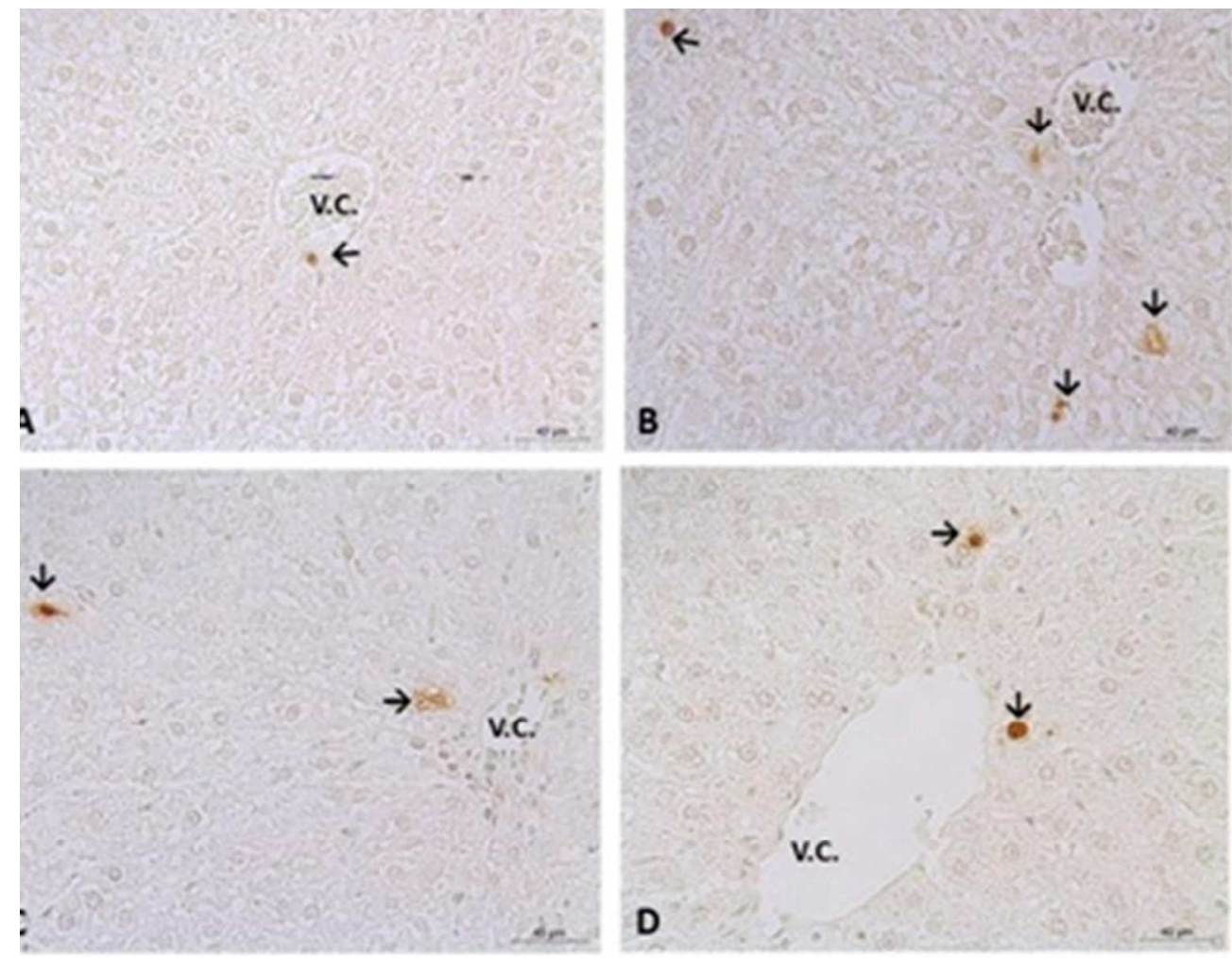

Figure 4

$279 \times 215 \mathrm{~mm}(300 \times 300 \mathrm{DPI})$ 